\title{
Fatal Deliberate Self Harm with Paraquat
}

\author{
MOHAMMED ISHAQUE MAJ UMDER, ${ }^{1}$ MOHAMMAD MAHFUZUL HOQUE, ${ }^{2}$ B.U.M WAHID AHMED, ${ }^{2}$ A. H.M WAШUR \\ RAHMAN, ${ }^{3}$ SHEI KH MOHAMMAD NOOR- E-ALAM, ${ }^{4}$ MD. ABUL FAI $Z^{5}$
}

\begin{abstract}
Deliberate self harm using paraquat is a significant problem in parts of Asia, the Pacific and Caribbean. It is used as herbicide and highly toxic after ingestion. Large amount of paraquat leads to rapid death but smaller doses often cause a delayed lung fibrosis. A 2 I-yr-old female patient with paraquat poisoning with complaints of retrosternal and epigastric pain, mild respiratory distress and jaundice was admitted. She was icteric, her pulse was fast, subcutaneous emphysema was found at neck and lung was clear. Her respiratory distress, renal and liver function deteriorated and the patient was shifted to ICU and died on fourth day of poisoning. Methylprednisolone and cyclophosphamide pulse therapy was given but the patient died from multi-organ failure. Paraquat is very toxic and has no antidote.
\end{abstract}

Keyword: Paraquat, gramoxone, herbicides, poisoning, Bangladesh

\section{Introduction}

Intentional self poisoning is very common in developing countries with wide range of substances. Though pesticide self poisoning is major clinical problem in developing countries killing 3,00,000 people per year, ingestion of paraquat has become significant method of self poisoning in part of Asia, the Pacific and Caribbean. ${ }^{1-4}$

Paraquat is a bipyridyl compound used as contact herbicide since $1962 .^{5-7}$ Accidental contamination to skin, eye or inhalation to lung may occur but most cases of paraquat poisoning result from ingestion. Effects depends on degree of severity of paraquat poisoning, mild poisoning can cause only oral irritation and gastric upset. ${ }^{8,9}$ Moderate to severity poisoning produces multiorgan failure including renal failure, hepatic failure, cardiotoxicity, cerebral oedema, pulmonary fibrosis, coma leading to death. ${ }^{10,11}$ Paraquat is thought to induce a metabolically catalyzed, single electron, reductionoxidation reaction, causing depletion of NADPH and subsequently lipid peroxidation and also generation of toxic forms of oxygen such as the superoxide free radical, hydroxyl radical etc. leading to cell damage. ${ }^{10,12,13}$ Acute multiorgan failure may occur within hours to days of exposure. If patient survives and dose is high enough, pulmonary fibrosis occurs. Lung damage occurs in two phases, initially from destructive alveolitis leading to ARDS and later on from proliferative phase leading to fibrosis. ${ }^{13}$
Therapy has concentrated on reducing paraquat absorption from GIT and increasing its elimination. All patient should receive activated charcoal (or fullers earth) as soon as possible. ${ }^{14}$ Continuous haemo-perfusion and veno-venous haemofiltration reduces the proportion of patient dying from acute multi-organ failure. ${ }^{15,16}$ No antidote is accepted as proven effective by adequate RCT. ${ }^{17}$ However use of cyclophosphamide and glucocorticoid pulse therapy is recommended by some experts given the lack of a proven antidote and reports of potential benefit from this regimen. ${ }^{18-20}$

An ingestion of $15 \mathrm{ml}$ of $20 \%$ paraquat solution is considered to be lethal. ${ }^{8}$ Multi-organ failure supervenes in severe poisoning and little can be done to reverse cardiovascular collapse. Mainstay of treatment is good supportive and palliative care of the patient and support to relatives and significant others. ${ }^{8}$

\section{Case report}

Mrs. M B, a 21-year-old, house wife got admitted in Mitford hospital, Dhaka on 27/09/09 at 15:20 hrs through emergency department as a case of suicidal poisoning with a substance used in agriculture for killing weeds. She was referred from a district hospital and mentioned poison on referral paper was paraquat (trade name-gramoxone) and that was also confirmed with container carried by patient's attendant. She was with the complaints of retrosternal and epigastric pain for 2 days and yellow discoloration of skin and sclera for 1 day.

1. Assistant Professor, Department of Medicine, Sir Salimullah Medical College, Mitford Hospital, Dhaka.

2. Assistant Registrar, Department of Medicine, Sir Salimullah Medical College, Mitford Hospital, Dhaka.

3. Indoor Medical Officer, Department of Medicine, Sir Salimullah Medical College, Mitford Hospital, Dhaka.

4. Registrar, Department of Medicine, Sir Salimullah Medical College, Mitford Hospital, Dhaka.

5. Professor and Head, Department of Medicine, Sir Salimullah Medical College \& Mitford Hospital, Dhaka.

Correspondence: Mohammed Ishaque Majumder, Assistant Professor, Department of Medicine, Sir Salimullah Medical College, Mitford Hospital, Dhaka. 


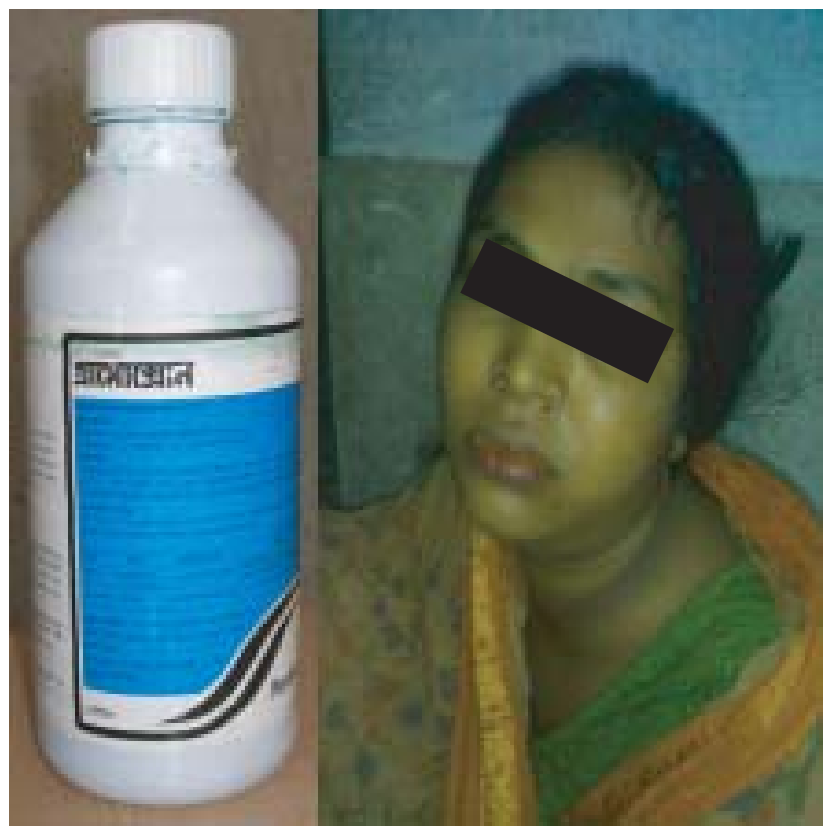

Fig.-1A: Container of paraquat, Fig.-1B: Patient of paraquat poisoning showing jaundice

The patient attempted suicide with ingestion of half a cup of mentioned herbicide 2 days back on 25.09.09 at 14 :00 hrs. After taking the herbicide, she developed vomiting followed by burning sensation in mouth, throat, and retrosternum. She was taken to nearby district hospital and stomach wash was given within two hours of poisoning .She was kept there nothing per os and treated with intravenous fluid, antibiotic, ranitidine and few ampoules of atropine which was given initially and discontinued later on. She developed upper abdominal pain along with retrosternal pain and vomiting mixed with scanty amount of blood for couple of times. After a day she developed yellow discoloration of skin and sclera and referred for tertiary care. She also had dry cough and mild shortness of breath. She did not have any history of sweating, salivation, weakness. Her bladder was catheterized and bowel movement was normal.

During admission, her face was puffy, mildly anaemic, moderately icteric, not cyanosed and mildly edematous. Her pulse was 134 b/min, BP was 130/90 mm Hg, Temperature was $99^{\circ} \mathrm{F}$, and respiratory rate was $26 \mathrm{~b} / \mathrm{min}$. There was no visible engorged neck vein but her neck was swollen and subcutaneous emphysema was found on palpation. She was oriented and flapping tremor was absent. Her upper abdomen was soft but tender, liver and spleen were not palpable and upper border of liver dullness was in right fifth intercostal space and bowel sound was present. Her lungs were clear and other systemic examination revealed normal findings. After admission her capillary blood sugar was 7.6 mmol/l and initial investigation are given in Table I.

She was treated with nothing per os with intravenous fluid, Ceftriaxone and injectable Omeprazole. Pulse methyleprednisolon (dose $15 \mathrm{mg} / \mathrm{kg}$ body weight) and cyclophosphamide (dose $15 \mathrm{mg} / \mathrm{kg}$ body weight) was started along with Inj. Mesna and vitamin C.

The condition of the patient was not improving. Her respiratory distress became worse, subcutaneous emphysema was increasing, pulse was becoming faster. She deserved to be under close monitoring and intervention in intensive care unit. The patient's party was consulted about

Table-I

Laboratory investigation result after admission

$\mathrm{CBC}-$

Haemoglobin - $9.6 \mathrm{~g} / \mathrm{dl}$

PCV-29\%

ESR- 44 in $1^{\text {st }}$ hour

WBC Total Count- 22,000/cmm Neutrophil-92\%

Platelet count- 395,000/cmm

Urine routine examination

Reaction- alkaline RBC- 20-30/ HPF
Albumin- +
Pus cell- 25-35/HPF
Sugar -+++
Granular cast- +

ECG - sinus tachycardia

CXR -normal findings

Urea $-116 \mathrm{mg} / \mathrm{dl}$

Creatinine $-4.7 \mathrm{mg} / \mathrm{dl}$

Bilirubin (total) $-13.8 \mathrm{mg} / \mathrm{dl}$

SGPT-227 u/L

SGOT-219u/L

Prothrombin time- $15 \mathrm{sec}$ (control-12 s)

Serum electrolyte-

$\mathrm{Na}^{+} \quad-134 \mathrm{mmol} / \mathrm{L} \quad \mathrm{K}^{+} \quad-3.2 \mathrm{mmol} / \mathrm{L}$

$\mathrm{Cl}^{-} \quad-97 \mathrm{mmol} / \mathrm{L} \quad \mathrm{CO} 2 \quad-21 \mathrm{mmol} / \mathrm{L}$ 
the condition of the patient and she was shifted to ICU, after 5 hours. We kept contact with the attendant over phone. She was treated there conservatively and was diagnosed as a case of organophosphorus poisoning with hepatic and renal failure. Initial blood gas analysis was found to be metabolic acidosis with hypoxaemia ( $\mathrm{pH}-7.25, \mathrm{PCO}_{2}-39$ mmHg, $\mathrm{PO}_{2}-82 \mathrm{mmHg}, \mathrm{BEb}-9.5 \mathrm{mmol} / \mathrm{L}$ ). On $2^{\text {nd }}$ day she was advised to have haemodialysis. The patient's attendants refused and took her back home. She was taken there as brought dead.

\section{Discussion}

Paraquat poisoning was not reported in Bangladesh, though it is in used many places. As organophosphorus poisoning is commonly used, poisoning with agricultural substance usually is regarded as organophosphorus poisoning. This young lady got atropine at district hospital initially, might have looked upon as an organophosphorus poisoning and it was confirmed as a paraquat poisoning when container was brought later on.

Just after ingestion the patient developed vomiting and burning sensation in mouth, throat, retrosternum and epigastrium. paraquat is locally corrosive and all her symptoms were due to corrosion and irritation. Stomach wash was given traditionally which aggravated her local injury as evident by vomiting mixed with scanty blood afterwards. Subcutaneous emphysema produced at neck is not a common feature of paraquat poisoning. Her initial chest x-ray was normal and subcutaneous emphysema may be due local corrosion and injury and stomach tube might have contributed too.

Amount of paraquat was taken shown by patient and her attendant and estimated quantity was $10-15 \mathrm{ml}$ of $27.6 \%$ paraquat solution. Her body weight was $53 \mathrm{~kg}$ and took about more than $50 \mathrm{mg} / \mathrm{kg}$ body weight which is very high. Jaundice appearing on day of poisoning indicated hepatotoxicity, renal function was also deteriorating. Progressive deteriorating renal and hepatic function is classical in paraquat poisoning which was prominent in this patient.

Respiratory distress was mild during admission but was increasing. Apart from subcutaneous emphysema in neck which was not enough severe to compress airway, chest examination was normal with normal chest $x$-ray indicated that her respiratory distress was probably due to metabolic acidosis $\left(\mathrm{PO}_{2}-82 \mathrm{~mm} \mathrm{Hg}\right.$ and $\left.\mathrm{pH}-7.2\right)$ rather than due to pneumonitis or ARDS. In ECG there was no arrhythmia, but her pulse was high indicated possibility of presence of cardiotoxicity.
Though methylpredinisolon and cyclophosphamide pulse therapy was given but it was not continued later on. Initial decontamination was not done properly, haemofiltration or haemoperfusion could not be provided and standard treatment of renal, hepatic and respiratory failure could not be provided.

\section{Conclusion}

As paraquat is not only highly toxic but also there is no antidote, proper precaution should be taken during marketing, storage and use to prevent exposure and keep out of reach of vulnerable group. Clinical feature of organophosphorus poisoning is distinct and paraquat poisoning should be in suspicion in case of poisoning with agricultural product without cholinergic toxicity. Provision of critical care is a necessity in major hospitals of the country for providing care to patients with multiorgan failure.

\section{Conflict of interest: None}

\section{References}

1 .Jeyaratnam J. Acute pesticide poisoning: a major global health problem. Wld Hlth Statist Q 1990; 43:139-144.

2. Eddleston M. Patterns and problems of deliberate selfpoisoning in the developing world. Q J Med 2000; 93:715731.

3. Eddleston M, Phillips MR. Self poisoning with pesticides. BMJ 2004; 328:42-44.

4. Buckley NA, Karalliedde L, Dawson A, Senanayake N, Eddleston $\mathrm{M}$. Where is the evidence for the management of pesticide poisoning - is clinical toxicology fiddling while the developing world burns? J Toxicol Clin Toxicol 2004; 42:113116.

5. World Health Organization. Environmental health criteria 39. paraquat and diquat. Geneva, IPCS Inchem, WHO, 1984.

6. World Health Organization. Poison information monograph 399. paraquat Geneva, IPCS Inchem, WHO, 1989.

7. Look EA, Wilks MF. paraquat. In: Handbook of pesticide toxicology, $2^{\text {nd }}$ edn. San Diego: Academic Press, 2001.

8. Vale. J. T. J. Meridith, and B.M. Buckly. 1987. Paraquat poisoning: clinical feature and immediate general management. Hum Toxicol 6:41-47.

9. Lin. J. L. 1900. Acute paraquat poisoning. Clin Med (Taiwan) 26:352-358.

10. Pond SM. Manifestations and management of paraquat poisoning. Med J Aust 1990; 152 (5): 256-9.

11. Jones AL, Elton R, Flanagan R. Multiple logistic regression analysis of plasma paraquat concentrations as a predictor of outcome in 375 cases of paraquat poisoning. QJM 1999; 92 (10): 573-8. 
12. Ballantyne B, Marrs T, Turner P, editors. General and applied toxicology college edition. New York: Stockton Press, 1995: 474-6.

13. Smith LL. The toxicity of paraquat. Adverse Drug React Acute Poisoning Rev 1988; 7 (1): 1-17.

14. Fountain JS, Beasley DM. Activated charcoal supersedes ipecac as gastric decontaminant. N Z Med J 1998; 111 (1076): 402-4.

15. Suzuki K, Takasu N, OkabeT, et al. Effect of aggressive haemoperfusion on the clinical course of patients with paraquat poisoning. Hum Exp Toxicol 1993;12:323-7.

16. Koo J-R, Kim J-C, Woon J-W, et al. Failure of continuous venovenous hemofiltration to prevent death in paraquat poisoning. Am J Kidney Dis 2002; 39:55-9.

17. Eddleston M, Wilks MF, Buckley NA. Prospects for treatment of paraquat-induced lung fibrosis with immunosuppressive drugs and the need for better prediction of outcome: a systematic review. QJM 2003; 96 (11): 80924. 3

18. Addo E, Ramdial S, Poon-King T. High dosage cyclophosphamide and dexamethasone treatment of paraquat poisoning with 75\% survival. West Indian Med J 1984; 33 (4): 220-6.

19. Lin JL, Wei MC, Liu YC. Pulse therapy with cyclophosphamide and methylprednisolone in patients with moderate to severe paraquat poisoning: a preliminary report. Thorax 1996; 51 (7): 661-3.

20. Lin JL, Leu ML, Liu YC, Chen GH. A prospective clinical trial of pulse therapy with glucocorticoid and cyclophosphamide in moderate to severe paraquat-poisoned patients. Am J Respir Crit Care Med 1999; 159 (2): 357-60. 